Огляди літератури, оригінальні дослідження, погляд на проблему

удК 616.122/123-007:[616.12-005.4+616.233-002.2]

DOI 10.11603/1811-2471.2017.v1.i3.8023

\title{
ОСОБЛИВОСТІ РЕМОДЕЛЮВАННЯ ЛІВИХ ТА ПРАВИХ ВІДДІЛІВ СЕРЦЯ ПАЦІЄНТІВ ІЗ ПОЄДНАНИМ ПЕРЕБІГОМ ІШЕМІЧНОЇ ХВОРОБИ СЕРЦЯ ТА ХРОНІЧНОГО ОБСТРУКТИВНОГО ЗАХВОРЮВАННЯ ЛЕГЕНЬ
}

\author{
Вінницький національний медичний університет імені М. І. Пирогова \\ ○Д. В. Діденко
}

PEзЮМЕ. Ішемічна хвороба серця (IXC) та хронічне обструктивне захворювання легень (ХОзЛ) - поширені патології в Україні та світі. Для цих захворювань характерні різні структурно-геометричні зміни камер серця, тому знання особливостей ехокардіографічних параметрів пацієнтів у випадку поєднаної патології $є$ актуальним.

Мета дослідження - визначити особливості ремоделювання камер серця у пацієнтів із поєднанням стабільної IXC та ХОЗЛ, встановити відмінності від показників пацієнтів з ізольованим перебігом даних патологій.

Матеріал і методи. У дослідження було включено 98 пацієнтів із поєднанням стабільної IXC та XОЗЛ, 96 осіб із стабільною IXC без супутнього ХОЗЛ та 78 пацієнтів із ХОЗЛ без супутньої IXC. Всім пацієнтам проведені загальноклінічне обстеження та ехокардіографія в М-та В-режимах.

Результати. Для осіб із коморбідною патологією характерними є більш виражені процеси ремоделювання лівого шлуночка (концентрична гіпертрофія у 21,4 \%, ексцентрична гіпертрофія у 23,5 \%), збільшення товщини стінок лівого шлуночка, тенденція до зниження фракції викиду, порівняно із пацієнтами з IXC без ХОЗЛ. Зміни правих відділів серця осіб із поєднанням IXC та ХОЗЛ відрізняються від показників пацієнтів з ХОзЛ без IXC, а саме більший розмір правого передсердя та збільшення частки пацієнтів із III типом ремоделювання правого шлуночка - перевантаження тиском та об'ємом - у 79,6 \%.

Висновки. Визначені зміни свідчать про формування синдрому взаємного обтяження у пацієнтів із поєднанням IXC та ХОЗЛ та ремоделювання камер серця, що відрізняють таких пацієнтів від осіб із ізольованим перебігом даних патологій.

КлючовІ словА: стабільна ішемічна хвороба серця; хронічне обструктивне захворювання легень; ехокардіографія; ремоделювання серця.

Вступ. Незважаючи на розвиток сучасної медичної науки, ішемічна хвороба серця (IXC) залишається однією із найпоширеніших патологій і основною причиною втрати працездатності та смертності в Україні $[1,2]$. За офіційною статистикою, в Україні в структурі IXC переважають стабільні форми захворювання, а саме стабільна стенокардія напруги (близько 33 \%), кардіосклероз та безбольова форма IXC [1].

У дослідженнях останніх років значна увага приділяється ремоделюванню камер серця за IXC, що може використовуватись для оцінки прогнозу цих пацієнтів $[3,4,5]$. Визначені особливості змін не лише лівого, а і правого шлуночка у пацієнтів із IXC, клапанними вадами, артеріальною гіпертензією. Дисфункція правого шлуночка визнана основним прогностичним маркером при лівошлуночковій серцевій недостатності [4]. В 2017 році проведено дослідження, що продемонструвало наявність дисфункції правого шлуночка у пацієнтів з серцевою недостатністю $(\mathrm{CH})$ за умови збереженої систолічної функції лівого шлуночка незалежно від рівня тиску в легеневій артерії [3]. Корекція симптомів СН $\epsilon$ суттєвою проблемою в курації пацієнтів з IXC.

Не менш значною $є$ і проблема діагностики та лікування хронічного обструктивного захворювання легень (ХОЗЛ), поширеність якого невпин- но зростає, особливо серед осіб старших вікових груп $[6,7]$. Загальновідомо, що ХОЗЛ $є$ системним захворюванням із позалегеневими проявами, в тому числі із впливом на структуру та функції серцево-судинної системи [8]. Зокрема, у у $90 \%$ пацієнтів з ХОЗЛ із тяжкими обструктивними змінами без супутньої серцевої патології визначалася діастолічна дисфункція лівого шлуночка [8], а близько $26 \%$ пацієнтів із ХОЗЛ мають систолічну дисфункцію лівого шлуночка, що корелює із тяжкістю захворювання [9].

Для IXC та ХОЗЛ характерні спільні фактори ризику та патогенетичні механізми, тому поєднання цих патологій зустрічається досить часто $[10,11]$. Через подібність клінічних симптомів захворювань та недооцінку впливу супутнього стану такі пацієнти можуть не отримувати адекватного контролю та лікування. Знання особливостей ехокардіографічних параметрів пацієнтів із поєднанням IXC та ХОЗЛ дозволить оцінити важкість стану, прогнозувати ризик серцево-судинних ускладнень та використовувати оптимальні схеми терапії.

Мета - визначити особливості ремоделювання камер серця у пацієнтів із поєднанням стабільної IXC та ХОЗЛ, Встановити відмінності від показників пацієнтів з ізольованим перебігом даних патологій. 
Огляди літератури, оригінальні дослідження, погляд на проблему

Матеріал і методи дослідження. Проведено клініко-функціональне обстеження 272 пацієнтів, що були поділені на 3 групи: в I групу увійшли 98 осіб із поєднанням стабільної IXC та ХОЗЛ середнього віку
$(65,8 \pm 0,83)$ років, II групу склали 96 пацієнтів із стабільною IXC без супутнього ХОЗЛ середнього віку $(58,9 \pm 0,9)$ років, у III групі було 78 осіб із ХОЗЛ без супутньої IXС середнього віку $(57,9 \pm 0,85)$ років (табл. 1).

Таблиця 1. Характеристика обстежених

\begin{tabular}{|c|c|c|c|c|}
\hline Показник & $\begin{array}{c}\text { Пацієнти з ІХС та ХОЗЛ } \\
\text { (група I) } \\
\text { n=98 }\end{array}$ & $\begin{array}{c}\text { Пацієнти з IXC } \\
\text { (група II) } \\
\text { n=96 }\end{array}$ & $\begin{array}{c}\text { Пацієнти з ХОЗЛ } \\
\text { (група III) } \\
\text { n=78 }\end{array}$ & $\mathrm{p}$ \\
\hline $\begin{array}{l}\text { Середній вік, } \\
\text { роки }\end{array}$ & $\begin{array}{c}65,8 \pm 0,83 \\
(58 ; 73)\end{array}$ & $\begin{array}{c}58,9 \pm 0,9 \\
(52,5 ; 66,5)\end{array}$ & $\begin{array}{l}57,9 \pm 0,85 \\
(53 ; 64)\end{array}$ & $\begin{array}{l}\mathrm{P}_{1-2}<0,001 \\
\mathrm{P}_{-3-3}<0,001 \\
\mathrm{P}_{2-3}=0,51\end{array}$ \\
\hline $\begin{array}{l}\text { Чоловіки, } \\
\text { абс., \% }\end{array}$ & $78(79,6 \%)$ & $70(72,9 \%)$ & 46 (59 \%) & $\begin{array}{l}\mathrm{P}_{1-2}=0,33 \\
\mathrm{P}_{1-3}=0,002 \\
\mathrm{P}_{2-3}=0,031\end{array}$ \\
\hline $\begin{array}{l}\text { Середній вік чоловіків, } \\
\text { роки }\end{array}$ & $\begin{array}{c}64,5 \pm 0,86 \\
(56 ; 72)\end{array}$ & $\begin{array}{c}56,9 \pm 0,88 \\
(51 ; 64)\end{array}$ & $\begin{array}{c}57,5 \pm 1,7 \\
(53 ; 63)\end{array}$ & $\begin{array}{l}\mathrm{P}_{1-2}<0,001 \\
\mathrm{P}_{1-3}<0,001 \\
\mathrm{P}_{2-3}=0,68\end{array}$ \\
\hline $\begin{array}{l}\text { Жінки, } \\
\text { абс., \% }\end{array}$ & $20(20,4 \%)$ & $26(27,1 \%)$ & 32 (41 \%) & $\begin{array}{l}\mathrm{P}_{1-2}=0,33 \\
\mathrm{P}_{1-3}=0,002 \\
\mathrm{P}_{2-3}=0,031\end{array}$ \\
\hline $\begin{array}{l}\text { Середній вік жінок, } \\
\text { роки }\end{array}$ & $\begin{array}{c}70,9 \pm 2,9 \\
(63 ; 74)\end{array}$ & $\begin{array}{l}64,5 \pm 2,7 \\
(57 ; 69)\end{array}$ & $\begin{array}{l}58,6 \pm 2,4 \\
(54 ; 65)\end{array}$ & $\begin{array}{l}\mathrm{P}_{1-2}=0,036 \\
\mathrm{P}_{1-3}<0,001 \\
\mathrm{P}_{2-3}=0,004\end{array}$ \\
\hline $\begin{array}{l}\mathrm{IMT} \\
\mathrm{KT} / \mathrm{M}^{2}\end{array}$ & $\begin{array}{c}30,5 \pm 0,56 \\
(26,7 ; 33)\end{array}$ & $\begin{array}{c}29,3 \pm 0,48 \\
(26 ; 32,6)\end{array}$ & $\begin{array}{c}29,2 \pm 0,77 \\
(24 ; 33,9)\end{array}$ & $\begin{array}{l}\mathrm{P}_{1-2}=0,19 \\
\mathrm{P}_{1-3}=0,13 \\
\mathrm{P}_{2-3}=0,56\end{array}$ \\
\hline $\begin{array}{l}\text { Куріння, } \\
\text { абс., \% }\end{array}$ & $70(71,4 \%)$ & $51(53,1 \%)$ & $44(56,4 \%)$ & $\begin{array}{l}\mathrm{P}_{1-2}=0,01 \\
\mathrm{P}_{1-3}=0,04 \\
\mathrm{P}_{2-3}=0,73\end{array}$ \\
\hline $\begin{array}{l}\text { Гіпертонічна хвороба, } \\
\text { абс., \% }\end{array}$ & $91(92,8 \%)$ & $84(87,5 \%)$ & $66(84,6 \%)$ & $\begin{array}{l}\mathrm{P}_{1-2}=0,21 \\
\mathrm{P}_{1-3}=0,09 \\
\mathrm{P}_{2-3}=0,65\end{array}$ \\
\hline $\begin{array}{l}\text { Цукровий діабет } \\
\text { абс., \% }\end{array}$ & $24(24,9 \%)$ & $14(14,6 \%)$ & $8(10,2 \%)$ & $\begin{array}{l}\mathrm{P}_{1-2}=0,07 \\
\mathrm{P}_{1-3}=0,01 \\
\mathrm{P}_{2-3}=0,346\end{array}$ \\
\hline $\begin{array}{l}\text { Захворювання ШКТ } \\
\text { абс., \% }\end{array}$ & $15(15,3 \%)$ & $27(28,1 \%)$ & $13(16,7 \%)$ & $\begin{array}{l}\mathrm{P}_{1-2}=0,043 \\
\mathrm{P}_{1-3}=0,98 \\
\mathrm{P}_{2-3}=0,06\end{array}$ \\
\hline
\end{tabular}

Примітки: 1. Дані кількісних показників представлені як $\mathrm{M} \pm \mathrm{m}$ - середнє значення \pm математична похибка середнього і як (рег25; рег75) - міжквартильний розмах (25 і 75 персантиль);

2. Порівняння відсотків між групами проводилось за критерієм $\chi^{2}$.

3. Порівняння медіан кількісних показників проводилось за критерієм U Манна-Уітні.

4. Достовірною вважалась різниця при $р<0,05$.

Пацієнти I групи були старші за осіб II та III груп $\left(\mathrm{p}_{1-2}<0,001, \mathrm{p}_{1-3}<0,001\right)$, така тенденція простежується і при гендерному розподілі - і чоловіки, і жінки I групи виявилися старшими за відповідних осіб інших груп. В усіх групах переважали пацієнти чоловічої статі, більшою була частка чоловіків в групі I та II $\left(p_{1-3}=0,002, p_{2-3}=0,031\right)$, також більша частка пацієнтів I групи курили $(71,4 \%)\left(p_{1-2}=0,012\right.$, $\left.\mathrm{P}_{1-3}=0,039\right)$. Обстежені пацієнти мали і іншу супутню патологію, найчастіше - гіпертонічну хворобу (ГХ), цукровий діабет (ЦД), хронічні захворювання шлунково-кишкового тракту (ШКТ). За нозоло- гіями IXC та клінічними групами ХОЗЛ групи були репрезентативними.

Усім пацієнтам була виконана ехокардіографія в M- та B-режимах («Logiq-500» фірми GE, CША) із оцінкою структурно-функціонального стану лівих та правих відділів серця. Визначали наступні показники: кінцевий систолічний розмір лівого шлуночка (КСО, мм), кінцевий діастолічний розмір лівого шлуночка (КДР, Мм), кінцевий систолічний об'єм лівого шлуночка (КСО, мл), кінцевий діастолічний об'єм лівого шлуночка (КДО, мл), фракцію викиду лівого шлуночка (ФВ, \%), швидкість ран- 
Огляди літератури, оригінальні дослідження, погляд на проблему

нього діастолічного наповнення лівого шлуночка (E, cм/c), швидкість пізнього діастолічного наповнення лівого шлуночка $(A, c M / c)$, співвідношення E/A, час сповільнення хвилі (DT, MC), товщину задньої стінки лівого шлуночка в діастолу (ТЗСЛШд, мм), товщину міжшлуночкової перетинки в діастолу (ТМШПд, мм), масу міокарда лівого шлуночка (ММЛШ, г), індекс маси міокарда лівого шлуночка (іММЛШ, г/см²), наявність ділянок гіпокінезу лівого шлуночка. Геометричну модель лівого шлуночка визначали згідно Ganau A. (1992), для чого виконували розрахунок відносної товщини міокарда (ВТМ, у.о.). Оцінку систолічної функції лівого шлуночка проводили на основі збільшення КДО, КСО та зменшення ФВ. Згідно з Рекомендаціями діагностики і лікування серцевої недостатності (2016) Європейського кардіологічного товариства, нормою вважали ФВ ЛШ >50 \%, зниженою - ФВ лШ <40 \%, проміжною «сірою зоною» ФВ ЛШ 40-50 \%. Також визначали розмір правого передсердя (ПП, мм), кінцевий діастолічний розмір правого шлуночка (ПШ, мм), товщину передньої стінки правого шлуночка (ПСПШ, см), систолічний тиск в легеневій артерії (СТЛА, мм рт. ст.) та оцінювали тип ремоделювання правого шлуночка.
Статистична обробка виконана за допомогою пакета програм «Statistica 7.0» (Statsoft.Inc., США). У випадку нормального розподілу показників для аналізу використовували параметричні методи (t-тест Стьюдента, дисперсійний аналіз (ANOVA). За ненормального розподілу були використані методи непараметричної статистики (U-тест Манна-Уітні, тест Краскела-Уолліса). Показники, що відображали частоту ознаки у вибірці, представлені у \%, кількісні показники наведені як «середнє значення \pm стандартна похибка середньої вели-

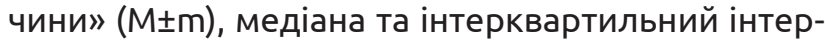
вал між 25-м та 75-м персантилями. Достовірними вважали результати порівнянь при значенні ймовірності похибки р<0,05.

Результати й обговорення. Встановлено, що всі пацієнти із поєднанням IXC та ХОЗЛ мали зміни, що характерні для ремоделювання лівих відділів, а саме збільшення розмірів порожнин лівого шлуночка (КДР та КСР, КДО, КСО) та лівого передсердя (ЛП), збільшення товщини стінок ЛШ (ТЗСЛШд та ТМШПд), ММЛШ, іММЛШ понад нормативні значення (табл. 2).

Порівнюючи наведені показники із аналогічними у пацієнтів з IXC без супутнього ХОЗЛ ми ви-

Таблиця 2. Характеристика параметрів лівих відділів серця пацієнтів різних груп

\begin{tabular}{|c|c|c|c|c|c|c|}
\hline Показник & $\begin{array}{c}\text { Група I } \\
\mathrm{n}=98\end{array}$ & $\begin{array}{c}\text { Група II } \\
\text { n=96 }\end{array}$ & $\begin{array}{c}\text { Група III } \\
\mathrm{n}=78 \\
\end{array}$ & $P_{1-2}$ & $P_{1-3}$ & $P_{2-3}$ \\
\hline КДР, мМ & $\begin{array}{l}54,4 \pm 0,87 \\
54(49 ; 57)\end{array}$ & $\begin{array}{c}52,4 \pm 0,7 \\
51(49 ; 56)\end{array}$ & $\begin{array}{l}49,2 \pm 0,77 \\
49(46 ; 52)\end{array}$ & 0,08 & $<0,001$ & 0,002 \\
\hline $\mathrm{KCP}, \mathrm{MM}$ & $\begin{array}{l}38,7 \pm 0,85 \\
38(34 ; 44)\end{array}$ & $\begin{array}{l}37,5 \pm 0,78 \\
37(33,41)\end{array}$ & $\begin{array}{l}32,5 \pm 0,74 \\
32(29 ; 35)\end{array}$ & 0,29 & $<0,001$ & $<0,001$ \\
\hline КСО, мл & $\begin{array}{c}72,4 \pm 4,16 \\
66,5(47 ; 90)\end{array}$ & $\begin{array}{c}63,5 \pm 3,5 \\
58(45 ; 75)\end{array}$ & $\begin{array}{c}46,9 \pm 3,5 \\
44(33 ; 51)\end{array}$ & 0,15 & $<0,001$ & $<0,001$ \\
\hline КДО, мл & $\begin{array}{c}141,7 \pm 5 \\
139,5(107 ; 160)\end{array}$ & $\begin{array}{c}137,2 \pm 4,8 \\
132(113,156)\end{array}$ & $\begin{array}{c}115,6 \pm 5 \\
111(95 ; 129)\end{array}$ & 0,51 & $<0,001$ & $<0,001$ \\
\hline ЛП, мм & $\begin{array}{l}40,5 \pm 1,15 \\
42(38 ; 45)\end{array}$ & $\begin{array}{l}40,4 \pm 0,45 \\
41(38 ; 42) \\
\end{array}$ & $\begin{array}{l}37,2 \pm 0,78 \\
37(35 ; 40)\end{array}$ & 0,09 & $<0,001$ & $<0,001$ \\
\hline ФB, \% & $\begin{array}{l}52,6 \pm 1,04 \\
51(46 ; 58) \\
\end{array}$ & $\begin{array}{c}54,1 \pm 1 \\
57(46,5 ; 60) \\
\end{array}$ & $\begin{array}{c}62 \pm 0,87 \\
63(58 ; 66) \\
\end{array}$ & 0,18 & $<0,001$ & $<0,001$ \\
\hline ТЗСЛШд,см & $\begin{array}{c}1,2 \pm 0,02 \\
1,2(1,1 ; 1,3) \\
\end{array}$ & $\begin{array}{c}1,1 \pm 0,02 \\
1,13(1 ; 1,2) \\
\end{array}$ & $\begin{array}{c}1 \pm 0,02 \\
1,1(1 ; 1,2) \\
\end{array}$ & 0,008 & $<0,001$ & 0,13 \\
\hline ТМШПд, см & $\begin{array}{c}1,2 \pm 0,02 \\
1,3(1,2 ; 1,3)\end{array}$ & $\begin{array}{c}1,1 \pm 0,02 \\
1,1(1 ; 1,2) \\
\end{array}$ & $\begin{array}{c}1 \pm 0,03 \\
1(0,95 ; 1,2) \\
\end{array}$ & 0,002 & $<0,001$ & 0,38 \\
\hline ММЛШ, г & $\begin{array}{c}279,8 \pm 10,1 \\
278(221 ; 331)\end{array}$ & $\begin{array}{c}233,9 \pm 7,6 \\
232(190 ; 268)\end{array}$ & $\begin{array}{c}213 \pm 9,6 \\
214(158 ; 264) \\
\end{array}$ & $<0,001$ & $<0,001$ & 0,03 \\
\hline 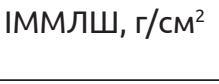 & $\begin{array}{c}138 \pm 4,6 \\
135(109 ; 157)\end{array}$ & $\begin{array}{c}116,9 \pm 3,5 \\
117(100 ; 139)\end{array}$ & $\begin{array}{c}107,8 \pm 4,7 \\
106(83 ; 125)\end{array}$ & $<0,001$ & $<0,001$ & 0,02 \\
\hline ВТМ, ум. од. & $\begin{array}{c}0,45 \pm 0,01 \\
0,45(0,39 ; 0,5) \\
\end{array}$ & $\begin{array}{c}0,43 \pm 0,01 \\
0,4(0,38 ; 0,48) \\
\end{array}$ & $\begin{array}{c}0,44 \pm 0,01 \\
0,4(0,4 ; 0,48) \\
\end{array}$ & 0,35 & 0,58 & 0,73 \\
\hline DT, MC & $\begin{array}{c}245,2 \pm 15 \\
249(222 ; 275)\end{array}$ & $\begin{array}{c}259,5 \pm 9,1 \\
246(235 ; 291)\end{array}$ & $\begin{array}{c}243,1 \pm 7,8 \\
240(214 ; 268)\end{array}$ & 0,67 & 0,41 & 0,11 \\
\hline
\end{tabular}

Примітки: 1. Дані кількісних показників представлені як $\mathrm{M} \pm \mathrm{m}$ - середнє значення \pm математична похибка середнього і як Мед (рег25; рег75) - медіана і міжквартильний розмах (25 і 75 персантиль);

2. Порівняння медіан кількісних показників проводилось за критерієм U Манна-Уітні.

3. Достовірною вважалась різниця при $p<0,05$. 
Огляди літератури, оригінальні дослідження, погляд на проблему

значили тенденцію до більш значної дилатації ЛШ у осіб із поєднаною патологією: КСО в І групі становив $(72,4 \pm 4)$ мл, в II групі - $(63,5 \pm 3)$ мл, КДО в I групі склав $(141,7 \pm 5)$ мл, в || - $(137,2 \pm 4)$ мл. Також наявна тенденція до зниження систолічної функції ЛШ (ФВ в І групі склала $(52,6 \pm 1) \%$ в в II групі $(54,1 \pm 1) \%)$. Встановлено достовірно вищі значення ТЗСЛШд, ТМШПд, ММЛШ та іММЛШ у осіб I групи, порівняно з II групою, що також свідчить про більш виражені процеси ремоделювання та гіпертрофічні зміни.

Був проведений розподіл пацієнтів різних груп за типами ремоделювання ЛШ згідно з крите- ріями Ganau A. (рис. 1). Встановлено, що в I групі нормальна геометрія ЛШ була наявна у 30 (30,6\%) осіб, тоді як у II групі -у 43 (44,8 \%), в ІІІ -у 46 (58,9\%) $\left(p_{1-2}=0,09, p_{1-3}=0,002, p_{2-3}=0,07\right)$, концентричне ремоделювання в I групі виявили у 24 (24,5\%) пацієнтів, в II групі - у 34 (35,4 \%), в III групі - у 23 (29,5\%), достовірної різниці між групами не визначено. Концентрична гіпертрофія діагностована частіше в I групі - у 21 (21,4 \%) особи, в |I групі - у 7 (7,3 \%), в III групі - у $8(10,3 \%)\left(p_{1-2}=0,024, p_{1-3}=0,05, p_{2-3}=0,52\right)$, ексцентрична гіпертрофія в I групі визначена у 23 (23,5 \%) обстежених, в ІІ групі -у 12 (12,5\%), в III груni-y $1(1,3 \%)\left(p_{1-2}=0,047, p_{1-3}=<0,001, p_{2-3}=0,027\right)$.

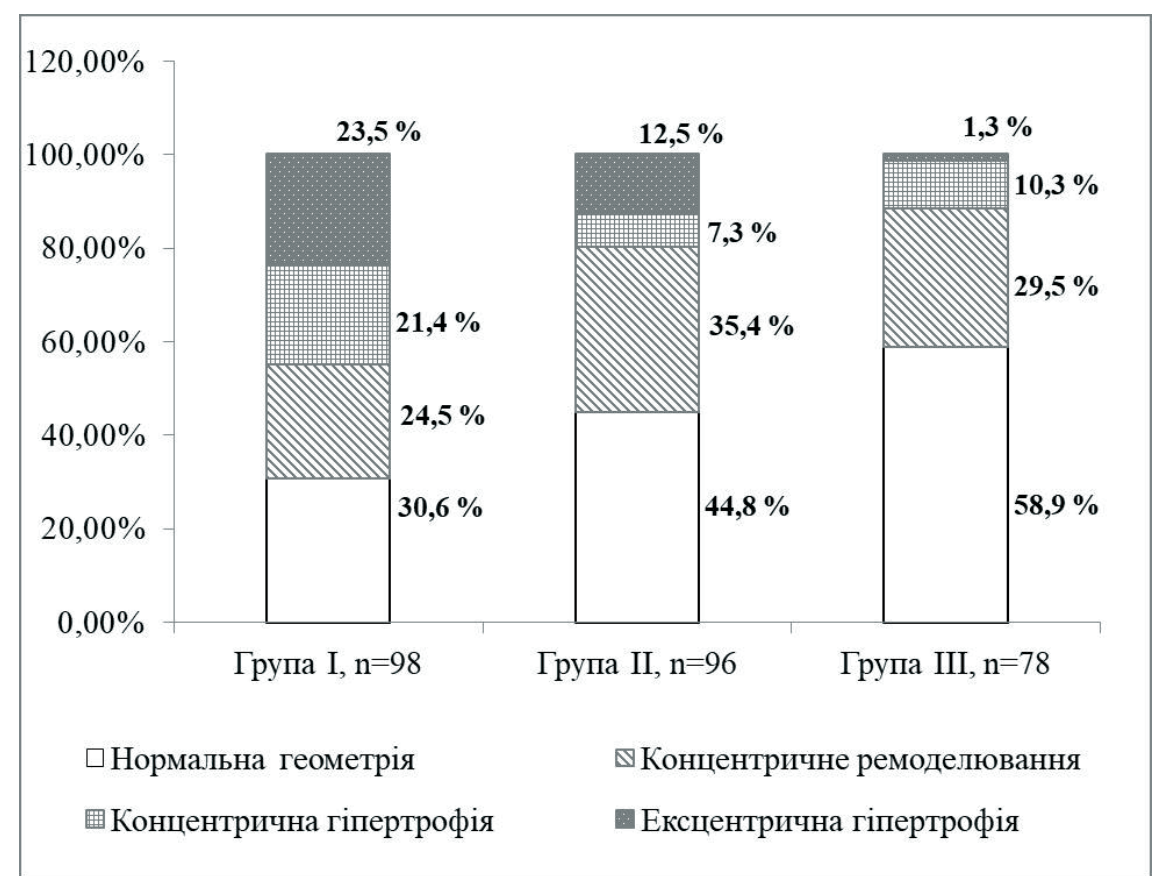

Рис. 1. Розподіл пацієнтів за типами ремоделювання лівого шлуночка.

Отже, серед пацієнтів із поєднанням IXC та ХОЗЛ спостерігалось достовірне переважання осіб із більш вираженими ознаками ремоделювання ЛШ, а саме 3 концентричною та ексцентричною гіпертрофією, що достовірно відрізнялось як від пацієнтів IXC без ХОЗЛ, так і від осіб із ХОЗЛ без супутньої IXC.

При аналізі систолічної функції ЛШ достовірна різниця кількості пацієнтів із ії порушенням визначена лише при порівнянні груп осіб, що мали IXC, та пацієнтів з ХОЗЛ без супутньої IXC: в I та II групах частка осіб із зниженою ФВ була 45 $(45,9 \%)$ та 34 (35,4\%) відповідно, наявна тенденція до зниження систолічної функції в I групі, тоді як у III групі переважна більшість - 74 (94,9 \%) пацієнтів мали нормальну систолічну функцію Лш (табл. 3).

Таблиця 3. Розподіл пацієнтів за систолічною функцією лівого шлуночка

\begin{tabular}{|l|c|c|c|c|c|c|}
\hline Показник ФВ & $\begin{array}{c}\text { Група I } \\
\mathrm{n}=98\end{array}$ & $\begin{array}{c}\text { Група II } \\
\mathrm{n}=96\end{array}$ & $\begin{array}{c}\text { Група III } \\
\mathrm{n}=78\end{array}$ & $\mathrm{P}_{1-2}$ & $\mathrm{P}_{1-3}$ & $\mathrm{P}_{2-3}$ \\
\hline $\begin{array}{l}>50 \% \\
\text { А6с., \% }\end{array}$ & $53(54,1 \%)$ & $62(64,6 \%)$ & $74(94,9 \%)$ & 0,17 & $<0,001$ & $<0,001$ \\
\hline $\begin{array}{l}40-50 \% \\
\text { A6c., \% }\end{array}$ & $41(41,8 \%)$ & $31(32,3 \%)$ & $\begin{array}{c}4 \\
(5,1 \%)\end{array}$ & 0,22 & $<0,001$ & $<0,001$ \\
\hline $\begin{array}{l}<40 \% \\
\text { Абс., \% }\end{array}$ & $4(4,1 \%)$ & $3(3,1 \%)$ & $0(0)$ & 0,67 & 0,09 & 0,17 \\
\hline
\end{tabular}

Примітки: 1. Порівняння відсотків між групами проводилось за критерієм $\chi^{2}$.

2. Достовірною вважалась різниця при $\mathrm{p}<0,05$. 
Огляди літератури, оригінальні дослідження, погляд на проблему

Проведено також розподіл пацієнтів за типом діастолічної дисфункції ЛШ (ДДЛШ) (рис. 2). В усіх групах обстежених найчастіше діагностували I тип - порушення релаксації, достовірно частіше в II групі - у 93 (96,9 \%) пацієнтів ( $p_{1-2}=0,01, p_{1-3}=0,52$, $\left.\mathrm{p}_{2-3}=0,002\right)$. ДДлШ за типом псевдонормалізації достовірно частіше визначали у осіб I групи - 10 $(10,2 \%)$, тоді як в ІІ групі - у 2 (2,1\%) пацієнтів та в
III групі - у $3(3,8 \%)\left(p_{1-2}=0,02, p_{1-3}=0,1, p_{2-3}=0,48\right)$. Нормальна діастолічна фунція була наявна у незначної частки пацієнтів з IXC, лише у 3 (3,1\%) осіб в I групі та в 1 (1 \%) в II групі, достовірно частіше спостерігалась в групі III - у 10 (12,9\%) пацієнтів $\left(\mathrm{p}_{1-2}=0,32, \mathrm{p}_{1-3}=0,01, \mathrm{p}_{2-3}=0,002\right)$. ДДлШ за peстриктивним типом не визначили у жодного обстеженого.

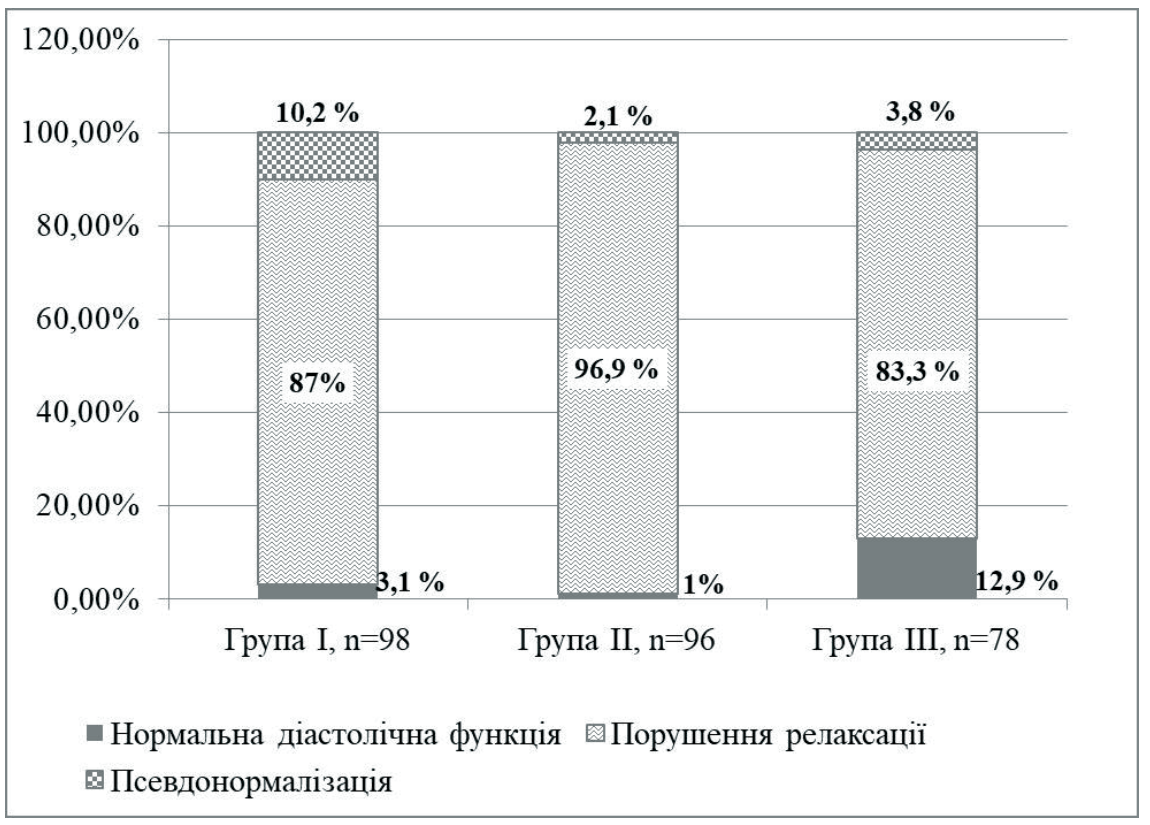

Рис. 2. Розподіл обстежених за типами діастолічної дисфункції лівого шлуночка.

Аналізуючи показники правих камер серця ми визначили достовірну відмінність між пацієнтами I та III груп за розміром ПП (41,5 та 38 мм рт. ст. відповідно, $p=0,01)$, а також тенден- цію до більшого розміру ПШ та тиску в ЛА у осіб I групи. Відмінність за розмірами ПСПШ, ПП та тиском в ЛА була достовірною між групами I та II (табл. 4).

Таблиця 4. Характеристика параметрів правих відділів серця пацієнтів різних груп

\begin{tabular}{|c|c|c|c|c|c|c|}
\hline Показник & $\begin{array}{c}\text { Група I } \\
\mathrm{n}=98\end{array}$ & $\begin{array}{c}\text { Група II } \\
\text { n=96 }\end{array}$ & $\begin{array}{c}\text { Група III } \\
\mathrm{n}=78\end{array}$ & $P_{1-2}$ & $P_{1-3}$ & $P_{2-3}$ \\
\hline ПШ, мм & $\begin{array}{c}27,1 \pm 0,6 \\
27(25 ; 28)\end{array}$ & $\begin{array}{c}26,1 \pm 0,4 \\
26(24 ; 28) \\
\end{array}$ & $\begin{array}{l}26,6 \pm 0,59 \\
26(24 ; 28)\end{array}$ & 0,12 & 0,13 & 0,9 \\
\hline ПСПШ, см & $\begin{array}{c}0,51 \pm 0,02 \\
0,5(0,45 ; 0,52)\end{array}$ & $\begin{array}{c}0,41 \pm 0,02 \\
0,4(0,38 ; 0,4)\end{array}$ & $\begin{array}{c}0,5 \pm 0,02 \\
0,5(0,4 ; 0,5)\end{array}$ & $<0,001$ & 0,69 & $<0,001$ \\
\hline ПП, мм & $\begin{array}{l}37,8 \pm 0,54 \\
38(35 ; 40)\end{array}$ & $\begin{array}{l}35,5 \pm 0,5 \\
35(34 ; 38)\end{array}$ & $\begin{array}{l}35,9 \pm 0,74 \\
35(32 ; 38)\end{array}$ & 0,005 & 0,01 & 0,94 \\
\hline $\begin{array}{l}\text { СТЛА, } \\
\text { мм Рт. ст. }\end{array}$ & $\begin{array}{c}41,7 \pm 1,1 \\
41,5(35,5 ; 48)\end{array}$ & $\begin{array}{c}37,4 \pm 1 \\
38(32 ; 41,7)\end{array}$ & $\begin{array}{c}40,4 \pm 1,7 \\
38(35 ; 44,5)\end{array}$ & 0,008 & 0,24 & 0,14 \\
\hline
\end{tabular}

Примітки: 1. Дані кількісних показників представлені як $\mathrm{M} \pm \mathrm{m}$ - середнє значення \pm математична похибка середнього і як Меd (рег25; рег75) - медіана і міжквартильний розмах (25 і 75 персантиль);

2. Порівняння медіан кількісних показників проводилось за критерієм U Манна-Уітні.

3. Достовірною вважалась різниця при р<0,05 при порівнянні показників між чоловіками та жінками.

У всіх пацієнтів I групи виявлені зміни геометрії ПШ, достовірно переважала частка осіб, котрі мали III тип ремоделювання ПШ (перевантаження тиском та об'ємом) - 78 (79,6 \%) ( $\mathrm{p}_{1-2}<0,001, \mathrm{p}_{1-3}=0,01$, $\left.\mathrm{P}_{2-3}<0,001\right)$, в той же час в інших групах наявні пацієн- ти із нормальною геометрією ПШ - 45 (45,8 \%) пацієнтів в II групі та 9 (11,5\%) - в III групі (рис. 3 ).

Наведені дані підтверджують формування синдрому взаємного обтяження IXC та ХОЗЛ за умови їх поєднання. Визначення структурно-функ- 


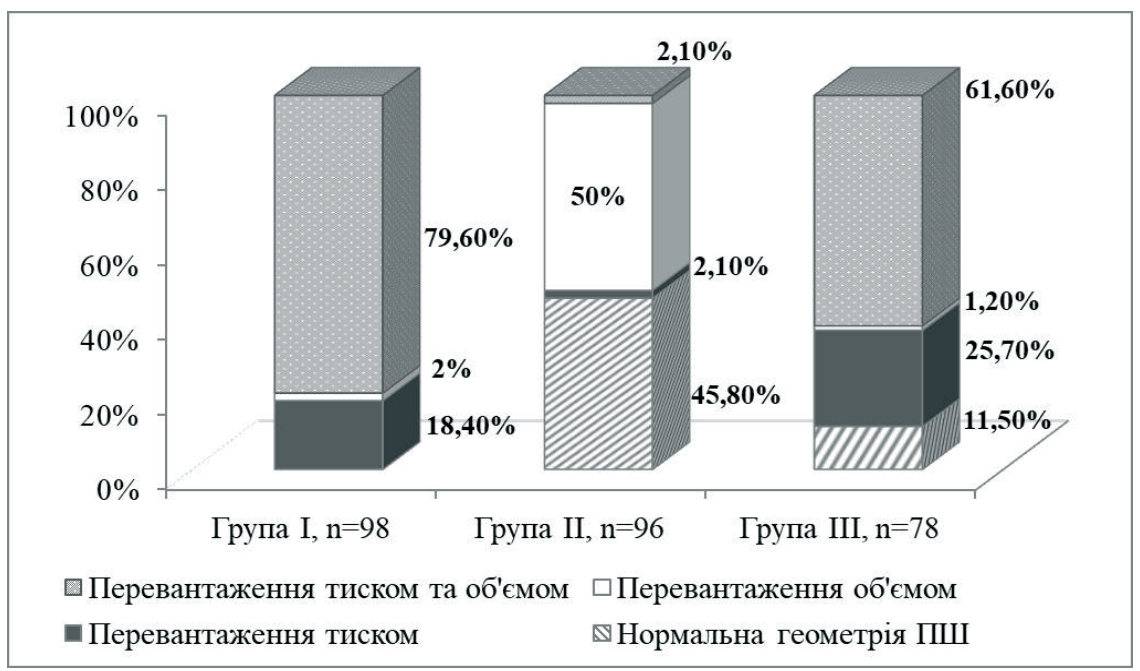

Рис. 3. Розподіл пацієнтів за типами ремоделювання правого шлуночка.

ціональних параметрів лівих та правих відділів серця за допомогою ехокардіографічного дослідження у пацієнтів із поєднанням IXC та ХОЗЛ дозволяє оцінити особливості ремоделювання в умовах гіпоксії, активації імунних механізмів та маркерів запалення, порушень мікроциркуляції, ендотеліальної дисфункції та ішемії міокарда.

Висновки. 1. Для осіб із поєднаною патологією характерними єзбільшення іММЛШ, ТЗСЛШд, ТМШПд, а також більш виражені процеси ремоделювання ЛШ (концентрична гіпертрофія у 21 (21,4\%), ексцентрична гіпертрофія у 23 (23,5 \%) пацієнтів) порівняно із пацієнтами з IXC без ХОЗЛ, що асоційовано із вищим ризиком серцево-судинних ускладнень.

2. За станом діастолічної функції в усіх групах переважають пацієнти із порушенням релаксації 86 (86,7 \%) але серед пацієнтів з поєднанням IXC та ХОЗЛ достовірно зростає частка осіб із псевдонормальним типом - 10 (10,2 \%).

\section{ЛІТЕРАТУРА}

1. Наказ МОЗ України № 555 «Про затвердження та впровадження медико-технологічних документів зі стандартизації медичної допомоги при хронічному обструктивному захворюванні легень» від 27.06.2013 [Електронний ресурс] / http://moz.gov.ua/ua/portal/ dn_20130627_0555.html

2. Epidemiology of coronary heart disease and acute coronarysyndrome / F. Sanchis-Gomar, C. Perez-Quilis, R. Leischik [et al.] // Ann. Transl. Med. - 2016. - Vol. 4 (13). P. 256-260.

3. Right ventricular dysfunction in left-sided heart failure with preserved versus reduced ejection fraction [Electronic Resource] / L. Bosch, C. Lam, L. Gong [et al.] // Eur. J. Heart Fail - 2017. - Published online 2017 June 8. Access mode : https://www.ncbi.nlm.nih.gov/ pubmed/28597497
3. Пацієнти із поєднанням IXC та ХОЗЛ мають зміни правих відділів серця, що відрізняються від показників пацієнтів з ХОЗЛ без IXC, а саме достовірно більший розмір ПП та збільшення частки пацієнтів із III типом ремоделювання правого шлуночка - перевантаження тиском та об'ємом 78 (79,6 \%) пацієнта.

Перспективи подальших досліджень. Перспективи дослідження можуть допомогти в курації пацієнтів із поєднаною патологією, а саме: розробити схеми лікування пацієнтів із поєднанням IXC та ХОЗЛ за допомогою використання ехокардіографічних параметрів. Доцільним є вивчення взаємообтяжувального впливу показників функції зовнішнього дихання та структурно-геометричного ремоделювання серця і впровадження діагностичних критеріїв відбору пацієнтів для запобігання розвитку серцевої недостатності.

4. Right ventricular function in heart failure with preserved ejection fraction: a community-based study / S. F. Mohammed, I. Hussain, O. Abou Ezzeddine // Circulation. - 2014. - Vol. 130 (25). - P. 2310-2320.

5. Meyer P. Effects of right ventricular ejection fraction on outcomes in chronic systolic heart failure / P. Meyer, M. White, A. Ali // Circulation. -2010. - Vol. 121. -P. 252-258.

6. Global Initiative for Chronic Obstructive Lung Disease (Updated 2017) [Electronic Resource] / Access mode : www.goldcopd.com

7. Наказ МОЗ України № 152 «Про затвердження та впровадження медико-технологічних документів зі стандартизації медичної допомоги при стабільній ішемічній хворобі серця» від 02.03.2016 [Електронний ресурс] / http://moz.gov.ua/ua/portal/dn_20160302_0152. html 
Огляди літератури, оригінальні дослідження, погляд на проблему

8. High Prevalence of Left Ventricle Diastolic Dysfunction in Severe COPD Associated with A Low Exercise Capacity: A Cross-Sectional Study / M. López-Sánchez, M. Muñoz-Esquerre, D. Huertas [et al.] // PLoS One. - 2013. Vol. 8 (6). - P. 135-142.

9. When left ventricular failure complicates chronic obstructive pulmonary disease: hypoxia plays the major role / B. Paudel, S. Dhungel, K. Paudel [et al.] // Kathmandu Univ. Med. J. (KUMJ). - 2008. - Vol. 6 (1). - P. 37-40.

\section{REFERENCES}

1. Moz.gov.ua. (2013) Nakaz MOZ Ukrainy №555 «Pro zatverdzhennia ta vprovadzhennia medyko-tekhnolohichnykh dokumentiv zi standartyzatsii medychnoi dopomohy pry khronichnomu obstruktyvnomu zakhvoriuvanni lehen» vid 27.06.2013. Access mode http://moz.gov.ua/ua/portal/ dn_20130627_0555.html [in Ukranian]

2. Sanchis-Gomar, F., Perez-Quilis, C., Leischik, R. and Lucia, A. (2016). Epidemiology of coronary heart disease and acute coronary syndrome. Annals of Translational Medicine, 4 (13), 256-256.

3. Bosch, L., Lam, C., Gong, L., Chan, S.P., Sim, D., \& Yeo, D. (2017). Right ventricular dysfunction in left-sided heart failure with preserved versus reduced ejection fraction. Eur. J. Heart Failure.

4. Mohammed, S., Hussain, I., Abou Ezzeddine, O., Takahama, H., Kwon, S., Forfia, P., Roger, V. \& Redfield, M. (2014). Right ventricular function in heart failure with preserved ejection fraction: a community-based study. Circulation, 130 (25), 2310-2320.

5. Meyer, P., White, M. \& Ali, A. (2009). Effect of reduced right ventricular ejection fraction on mortality in advanced systolic heart failure. Journal of Cardiac Failure, 15 (6), 88-89.

6. Global initiative for chronic obstructive lung disease (Updated 2017) [ Electronic Resource] / Access mode: www.goldcopd.com
10. Coronary artery disease concomitant with chronic obstructive pulmonary disease / S. Roversi, P. Roversi, G. Spadafora [et al.]//Eur. J. Clin. Invest. -2013. - Vol. 44 (1).P. 93-102.

11. Impact of chronic obstructive pulmonary disease on morbidity and mortality after myocardial infarction [Electronic Resource] / P. Andell. S. Koul, A. Martinsson [et al.] // Open Heart. - 2014. - Vol. 1(1). - Published online 2014 Feb 3. Access mode https://www.ncbi.nlm.nih.gov/pmc/articles/PMC4189340/pdf/openhrt-2013-000002.pdf
7. Moz.gov.ua. (2016) Nakaz MOZ Ukrainy №152 «Pro zatverdzhennia ta vprovadzhennia medyko-tekhnolohichnykh dokumentiv zi standartyzatsii medychnoi dopomohy pry stabilnii ishemichnii khvorobi sertsia» vid 02.03.2016. Access mode http://moz.gov.ua/ua/portal/dn_20160302_ 0152.html [in Ukranian]

8. López-Sánchez, M., Muñoz-Esquerre, M., Huertas, D., Gonzalez-Costello, J., Ribas, J., Manresa, F., Dorca, J. \& Santos, S. (2013). High prevalence of left ventricle diastolic dysfunction in severe COPD associated with a low exercise capacity: a cross-sectional study. PLOS ONE, 8 (6), 135-142.

9. Paudel, B., Dhungel, S., Paudel, K., Pandru, K., \& Paude, R. (2008). When left ventricular failure complicates chronic obstructive pulmonary disease: hypoxia plays the major role. Kathmandu Univ. Med. J. (KUMJ), 6 (1), 37-40.

10. Roversi, S., Roversi, P., Spadafora, G., Rossi, R. \& Fabbri, L. (2013). Coronary artery disease concomitant with chronic obstructive pulmonary disease. European Journal of Clinical Investigation, 44 (1), 93-102.

11. Andell, P., Koul, S., Martinsson, A., Sundström, J., Jernberg, T., Smith, J., James, S., Lindahl, B. \& Erlinge, D. (2014). Impact of chronic obstructive pulmonary disease on morbidity and mortality after myocardial infarction. Open Heart, 1 (1), p.e000002.

\title{
ОСОБЕННОСТИ РЕМОДЕЛИРОВАНИЯ ЛЕВЫХ И ПРАВЫХ ОТДЕЛОВ СЕРДЦА ПАЦИЕНТОВ С СОЧЕТАНИЕМ ИШЕМИЧЕСКОЙ БОЛЕЗНИ СЕРДЦА И ХРОНИЧЕСКОГО ОБСТРУКТИВНОГО ЗАБОЛЕВАНИЯ ЛЕГКИХ
}

๑Д. В. Диденко

\author{
Винницкий национальный медицинский университет имени Н. И. Пирогова, Винница
}

РЕЗЮМЕ. Ишемическая болезнь сердца (ИБС) и хроническое обструктивное заболевание легких (ХОзЛ) распространенные патологии в Украине и в мире. Для данных заболеваний характерны различные структурногеометрические изменения камер сердца, потому знание особенностей эхокардиографических параметров в случае сочетанной патологи актуально.

Цель исследования - определить особенности ремоделирования камер сердца у пациентов с сочетанием стабильной ИБС и ХОЗЛ, установить отличия от показателей пациентов с изолированным течением данных патологий.

Материал и методы. В исследование было включено 98 пациентов с сочетанием стабильной ИБС и ХОЗЛ, 96 лиц со стабильной ИБС без ХОЗЛ и 78 пациентов с ХОЗЛ без сопутствующей ИБС. Всем пациентам проведено общеклиническое обследование и эхокардиография в М- и В- режимах.

Результаты. Для пациентов с коморбидной патологией характерны более выраженные процессы ремоделирования левого желудочка (концентрическая гипертрофия у 21,4 \%, эксцентрическая гипертрофия у 
Огляди літератури, оригінальні дослідження, погляд на проблему

23,5 \%), увеличение толщины левого желудочка, тенденция к снижению фракции выброса по сравнению с пациентами ИБС без ХОЗЛ. Изменения правых отделов сердца обследованных с ИБС и ХОЗЛ также отличались от показателей пациентов с ХОЗЛ без сопутствующей ИБС, а именно больший размер правого предсердия и увеличение доли пациентов с III типом ремоделирования правого желудочка - перегрузки давлением и объемом (у $79,6 \%)$.

Выводы. Диагностированные изменения свидетельствуют о формировании синдрома взаимного отягощения у пациентов с сочетанием ИБС и ХОЗЛ и ремоделировании камер сердца, что отличается от случаев изолированных патологий.

КЛЮчЕВЫЕ СЛОВА: стабильная ишемическая болезнь сердца; хроническое обструктивное заболевание легких; эхокардиография; ремоделирование сердца.

\section{FEATURES OF REMODELING OF LEFT AND RIGHT HEART IN PATIENTS WITH COMBINATION OF ISCHEMIC HEART DISEASE AND CHRONIC OBSTRUCTIVE PULMONARY DISEASE}

OD. V. Didenko

\section{Pyrohov Vinnytsia National Medical University}

SUMMARY. Ischemic heart disease (IHD) and chronic obstructive pulmonary disease (COPD) are common diseases in Ukraine and in the world. Both diseases are characterized by different structural-geometrical changes of heart compartments, for this reason knowledge of features of echocardiographic parameters in case of comorbidity is important.

The aim of the study was to determine features of remodeling of heart compartments in patients with combination of stable IHD and COPD, to establish differences from indices of patients with isolated course of these diseases.

Materials and Methods. The study included 98 patients with combination of stable IHD and COPD, 96 patients with stable IHD without concomitant COPD and 78 patients with COPD without IHD. Typical clinical examination, M- and B-mode echocardiography were conducted.

Results. Patients with combined pathology were found more pronounced process of left ventricle remodeling (concentric hypertrophy in $21.4 \%$, eccentric hypertrophy in $23.5 \%$ ), increase of left ventricular wall thickness, the tendency to decrement of left ventricular ejection fraction as compared to patients with IHD. Changes of right heart of patients with IHD and COPD were distinguished from indices of patients with isolated COPD, that is significantly bidder right atrium and increase in the proportion of people with III type of right ventricle remodeling -pressure and volume overload in $79.6 \%$.

Conclusions. Determined changes are illustrative of reciprocal influence of IHD and COPD. Cardiac remodeling in case of combined pathology differs from indices of patients with isolated course of these diseases.

KEY WORDS: stable ischemic heart disease; chronic obstructive pulmonary disease; echocardiography; cardiac remodeling.

Отримано 8.08.2017 